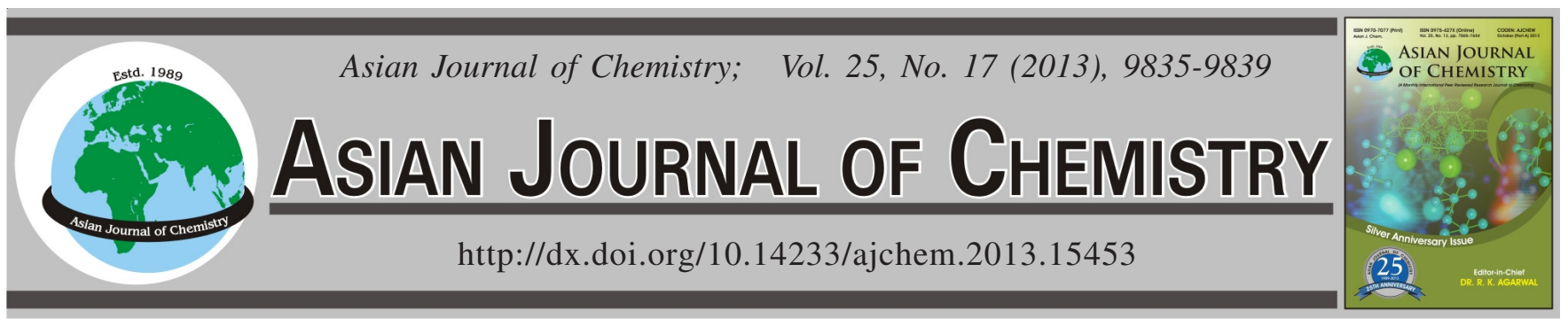

\title{
Synthesis of New Coumarin Compounds and Its Hypoglycemic Activity and Structure-Activity Relationship
}

\author{
GANG QI ${ }^{*}$ and WenguO ZHANG
}

Department of Chemistry and Biology, Yancheng Institute of Technology, Yancheng 224051, P.R. China

*Corresponding author: E-mail: qigang@ycit.cn

\section{INTRODUCTION}

Non-insulin-dependent diabetes is quite common in the middle-aged people and as the cause is different, a single hypoglycemic agent gets poor efficacy and long-term medication secondary shows high efficiency. Therefore, the combination can control the disease effectively and achieve better efficacy $^{1}$. As reported in the literature ${ }^{2}$ that the coumarin got hypoglycemic activity evidently and sulfonylurea compounds were also commonly used as hypoglycemic agents. Sulfonylurea hypoglycemic drugs could act on pancreatic cells selectively, promoting the secretion of insulin and then got hypoglycemic effect on normal subjects and diabetes. But the vivo pancreatic cells secreting insulin must be present in vivo, so such drug could not have hypoglycemic effect on the class of type1 diabetes or alloxan hyperglycemia rat animal model. However, experiments ${ }^{3}$ show coumarin could have hypoglycemic effect on the normal murine animal model and alloxan hyperglycemia mice animal models, which indicates its mechanism of action is different with the sulfonylurea hypoglycemic drugs. In addition, coumarin also has antibacterial, anti-coagulation action and plays a remedial role on diabetic complication ${ }^{4}$. So our group put sulfonylurea and coumarin together and then introduced an electron-withdrawing group in order to obtain high activity, synthesized the 3-bromocoumarin sulfonylurea compounds (I). Further, the changing substituted position of sulfonylurea on the parent ring of coumarin made it substitute in the 7-position in place of the 6-position, in order to investigate the impact of the substituted position of sulfonylurea group on the hypoglycemic activity and thereby 6-methylcoumarin sulfonylurea series of compounds (II) were synthesized.<smiles>[R]c1cc2oc(=O)c(Br)c([R])c2cc1[S+]([R10])([R12])O[Na]</smiles><smiles>Cc1cc2ccc(=O)oc2cc1S(=O)(=O)NC=O</smiles>

Preparation of 3-bromocoumarin sulfonylurea compounds (I): There are two routes to prepare the 3-bromocoumarin sulfonylurea compounds. Route 1 is shown in Fig. 1. The coumarin after addition of bromine were taken hydrogen bromide out and then obtained 3-bromocoumarin sulfonamides by chlorosulfonation and ammonification. Finally, the resultant was reacted with isocyanate to obtain the target compounds. In route 2 the resultant 3-bromocoumarin sulfonamides was reacted with ethyl chloroformate to obtain 3-bromocoumarin sulfamido ethyl ester and the synthetic object was then reacted with the corresponding primary amine, but failed.

The coumarin and substitutive coumarin can be obtained by Pechmann condensation reaction. 7-Methylcoumarin and 4,7-dimethylcoumarin were synthesized according to the literature ${ }^{5}$. 3-Bromocoumarin and 3-bromo-substituted coumarin were synthesized by synthetic route $^{6}$ (Fig. 1). In Fig. 1 the 
Route1<smiles>[R2]NC(=O)NOS(=O)(=O)c1cc2c([R])c(Br)c(=O)oc2cc1[R5](=O)[O-]</smiles>

\section{Route2}<smiles>[R]NC(=O)NOS(=O)(=O)c1cc2c([R7])c(Br)c(=O)c(=O)oc2cc1[R2]</smiles>

Fig.1. Synthesis route of 3-bromine-6-sulfonylurea-coumarin compounds

temperature had a great influence on the addition reaction of bromine in the first step reaction, the optimum temperature at around $20^{\circ} \mathrm{C}$. The high temperature could cause bromine to escape easily and then got the low yield. The low temperature could cause the reaction slowly. In the second step the sulfonyl chloride of coumarin was easy to hydrolyze by changing ambient conditions to heat under reflux and causing the reaction time reduce from $10 \mathrm{~h}$ to $3 \mathrm{~h}$ in the pyridine catalytic reaction of hydrogen bromide. Meanwhile, the introduction of electron-withdrawing caused the reaction hydrolyze more easily. Experiments found that the introduction of a bromine atom in the nucleus caused the production rate decrease and the introduction of a nitro group or an acetyl group can not obtain the sulfonyl chloride, which were hydrolyzed to generate a sulfonic acid. Further, the sulfonamides were also easy to hydrolyze as heated in the acidic condition, which was required to be neutral in the post processing; otherwise the yield would be decreased. Moreover, the product would be much better by using water replace ethanol in the process of recrystallization. The reaction conditions were subject to change due to the change of property caused by the introduction of the methyl. In the sulfochlorination reaction of methylsubstituted coumarin, the molar ratio of the reactant was changed; and the amount of chlorosulfonic acid was changed from 2.5 times to 4 times the amount of the raw material. There are several methods to synthesize the isocyanate, in the experiment the solid triphosgene was reacted with amine. That is because triphosgene is a white solid, easy to weigh and with low price.

Preparation of 6-methylcoumarin sulfonylurea compounds (II): In the post treatment process of the synthesis of 6-methylcoumarin ${ }^{7}$, using steam distillation to replace solvent extraction or vacuum distillation not only could improve the yield, but also made the operation simple. The reaction yield of 6-methylcoumarin chlorosulfonation is very low, trying to change the different reaction conditions to improve the yield (Fig. 2). The literature ${ }^{8}$ reported in the reaction of chlorosulfonation process, the reaction system was viscous and could join inert organic solvent. The liquidity of solution was enhanced due to the dispersion of the solvent and then the yield of the reaction was improved. But in the experiment adding organic solvent did not improve the yield of the reaction and increasing the temperature could make the yield increase, but the yield was still low.

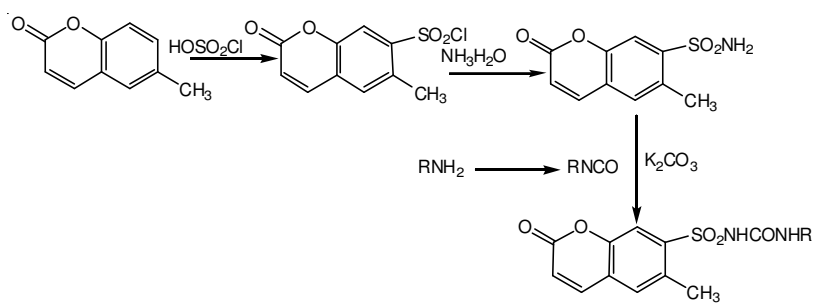

Fig. 2. Synthesis route of 7-sulfonylurea-coumarin compounds

\section{EXPERIMENTAL}

The melting point was determine by XT-4 binocular microscope and the thermometer was not corrected; Infrared spectrometer (Nicolet Impact 410); Nuclear magnetic resonance (Bruker ACF-300, TMS used as the internal standard); Mass spectrometer (HP1100LC/MSD). The reagents was analytically pure.

General method for synthesis of isocyanate: The solid triphosgene $(0.40 \mathrm{mo} 1)$ was dissolved in $50 \mathrm{~mL}$ chloroform; after stirring dissolved the $10 \mathrm{~mL}$ chloroform solution of corresponding amine $(0.20 \mathrm{~mol})$ was dripped with ice bath cooling. The reaction was occurred within $1 \mathrm{~h}$ at room temperature and heated with reflux for $6 \mathrm{~h}$, then obtained corresponding products by distillation.

General method for synthesis of the target compound: The sulfonamide $(1 \mathrm{~g}, 3.01 \mathrm{mmo1})$ was mixed with $20 \mathrm{~mL}$ acetone, adding potassium carbonate $(1 \mathrm{~g}, 7.2 \mathrm{mmo})$ and then the reaction mixture was heated with reflux for $1 \mathrm{~h}$. The solution was dripped into the acetone solution of isocyanate (3.14 mmo1) with backflow for $6 \mathrm{~h}$. Cooling and filtering the product, then the filter cake was dissolved with $20 \mathrm{~mL}$ water. The solid was obtained by adjusting $\mathrm{pH}=1$ with $20 \mathrm{~mL}$ concentrated hydrochloric acid and then the solution was neutral by filtering and washing with water. The products were dried. The data of the yield, melting point, infrared spectroscopy, nuclear magnetic resonance spectroscopy, high resolution mass spectrometry of the partial target compounds BSU-1BSU-14 were shown in Table-1. 
TABLE-1

PHYSICAL CONSTANTS, YIELDS AND SPECTRA DATA OF THE COMPOUNDS

\begin{tabular}{|c|c|c|c|c|c|c|c|c|}
\hline Compd. & $\mathrm{R}$ & $\mathrm{R}_{1}$ & $\mathrm{R}_{2}$ & Formula & $\begin{array}{l}\text { Yield } \\
(\%)\end{array}$ & $\begin{array}{l}\text { m.p. } \\
\left({ }^{\circ} \mathrm{C}\right)\end{array}$ & $\operatorname{IR}\left(\mathrm{cm}^{-1}\right)$ & ${ }^{1} \mathrm{H}$ NMR(DMSO- $\left.d_{6}\right) \delta$ \\
\hline BMSU-1 & $-\mathrm{CH}_{2} \mathrm{CH}_{2} \mathrm{CH}_{3}$ & $\mathrm{H}$ & $\mathrm{H}$ & 386.9645 & 80 & $138-140$ & $\begin{array}{l}3371,3072,1752, \\
1688,1605,1537 \\
1340,1159\end{array}$ & $\begin{array}{l}0.74-0.78(3 \mathrm{H}, \mathrm{t}), 1.24-1.39(2 \mathrm{H}, \mathrm{m}), 2.60-2.91 \\
(2 \mathrm{H}, \mathrm{t}), 6.44(1 \mathrm{H}, \mathrm{br}), 7.59-7.62(1 \mathrm{H}, \mathrm{d}), \\
8.06-8.09(1 \mathrm{H}, \mathrm{dd}), 8.28(1 \mathrm{H}, \mathrm{s}), 8.79(1 \mathrm{H}, \mathrm{s}), \\
10.70(1 \mathrm{H}, \mathrm{br})\end{array}$ \\
\hline BMSU-2 & $-\mathrm{CH}_{2}\left(\mathrm{CH}_{2}\right)_{2} \mathrm{CH}_{3}$ & $\mathrm{H}$ & $\mathrm{H}$ & 400.9777 & 77 & 94-95 & $\begin{array}{l}3370,3072,1757 \\
1683,1605,1538 \\
1338,1157\end{array}$ & $\begin{array}{l}0.79-0.83(3 \mathrm{H}, \mathrm{t}), 1.14-1.34(4 \mathrm{H}, \mathrm{m}), 2.85-2.91 \\
(2 \mathrm{H}, \mathrm{t}), 6.24(1 \mathrm{H}, \mathrm{br}), 7.53-7.56(1 \mathrm{H}, \mathrm{d}), \\
8.03-8.07(1 \mathrm{H}, \mathrm{dd}), 8.22(1 \mathrm{H}, \mathrm{s}), 8.76(1 \mathrm{H}, \mathrm{s})\end{array}$ \\
\hline BMSU-3 & $-\mathrm{CH}_{2} \mathrm{CH}\left(\mathrm{CH}_{3}\right)_{2}$ & $\mathrm{H}$ & $\mathrm{H}$ & 400.9820 & 65 & 104-107 & $\begin{array}{l}3382,3073,1756 \\
1688,1606,1547 \\
1340,1158\end{array}$ & $\begin{array}{l}0.74-0.76(6 \mathrm{H}, \mathrm{d}), 1.56-1.62(1 \mathrm{H}, \mathrm{m}), 2.65-2.77 \\
(2 \mathrm{H}, \mathrm{m}), 6.39(1 \mathrm{H}, \mathrm{br}), 7.57-7.60(1 \mathrm{H}, \mathrm{d}), 8.06- \\
8.09(1 \mathrm{H}, \mathrm{d}), 8.26(1 \mathrm{H}, \mathrm{s}), 8.78(1 \mathrm{H}, \mathrm{s}), 10.67 \\
(1 \mathrm{H}, \mathrm{br})\end{array}$ \\
\hline BMSU-4 & $-\mathrm{CH}_{2}\left(\mathrm{CH}_{2}\right) \mathrm{CH}_{3}$ & $\mathrm{H}$ & $\mathrm{H}$ & 414.9949 & 71 & $122-125$ & $\begin{array}{l}3369,3069,1753 \\
16189, \quad 1605 \\
1536,1342,1160\end{array}$ & $\begin{array}{l}0.78-0.83(3 \mathrm{H}, \mathrm{t}), 1.12-1.33(6 \mathrm{H}, \mathrm{m}), 2.87-2.93 \\
(2 \mathrm{H}, \mathrm{t}), 6.38(1 \mathrm{H}, \mathrm{br}), 7.58-7.61(1 \mathrm{H}, \mathrm{d}), 8.05- \\
8.09(1 \mathrm{H}, \mathrm{dd}), 8.26(1 \mathrm{H}, \mathrm{s}), 8.78(1 \mathrm{H}, \mathrm{s}), \\
10.69(1 \mathrm{H}, \mathrm{br})\end{array}$ \\
\hline BMSU-5 & & $\mathrm{H}$ & $-\mathrm{CH}_{3}$ & 448.9801 & 64 & $236-238$ & $\begin{array}{l}3335,3052,1717 \\
1609,1553,1330 \\
13159\end{array}$ & $\begin{array}{l}2.12(3 \mathrm{H}, \mathrm{s}), 2.68(3 \mathrm{H}, \mathrm{s}), 6.85-6.89(1 \mathrm{H}, \mathrm{d}), \\
6.99-7.10(2 \mathrm{H}, \mathrm{m}), 7.45(1 \mathrm{H}, \mathrm{br}), 7.59(1 \mathrm{H}, \mathrm{d}), \\
7.77(1 \mathrm{H}, \mathrm{br}), 8.30(1 \mathrm{H}, \mathrm{s}), 8.75(1 \mathrm{H}, \mathrm{s})\end{array}$ \\
\hline BMSU-6 & & $\mathrm{H}$ & $-\mathrm{CH}_{3}$ & 434.9645 & 72 & $156-157$ & $\begin{array}{l}3335,3055,1727 \\
1614,1547,1338 \\
1146\end{array}$ & $\begin{array}{l}2.66(3 \mathrm{H}, \mathrm{s}), 6.69-6.74(1 \mathrm{H}, \mathrm{t}), 7.03-7.08(2 \mathrm{H}, \\
\text { t), } 7.26(1 \mathrm{H}, \mathrm{s}), 7.37-7.40(2 \mathrm{H}, \mathrm{d}), 8.21(1 \mathrm{H}, \mathrm{s}), \\
8.40(1 \mathrm{H}, \mathrm{br}), 8.75(1 \mathrm{H}, \mathrm{s})\end{array}$ \\
\hline BMSU-7 & & $\mathrm{H}$ & $-\mathrm{CH}_{3}$ & 462.9958 & 69 & $148-149$ & $\begin{array}{l}3370,3070,1730 \\
1613,1547,1344 \\
1154\end{array}$ & $\begin{array}{l}2.01(3 \mathrm{H}, \mathrm{s}), 2.09(3 \mathrm{H}, \mathrm{s}), 2.67(3 \mathrm{H}, \mathrm{s}), 6.67- \\
6.70(1 \mathrm{H}, \mathrm{d}), 6.81-6.86(1 \mathrm{H}, \mathrm{t}), 7.25(1 \mathrm{H}, \mathrm{s}) \\
7.39-7.41(1 \mathrm{H}, \mathrm{d}), 8.16(1 \mathrm{H}, \mathrm{s}), 8.75(1 \mathrm{H}, \mathrm{s})\end{array}$ \\
\hline BSU-8 & $-\mathrm{CH}_{2}\left(\mathrm{CH}_{2}\right)_{2} \mathrm{CH}_{3}$ & $\mathrm{H}$ & $-\mathrm{CH}_{3}$ & 414.9958 & 80 & $82-85$ & $\begin{array}{l}3363,3073,1750 \\
1722,1635,1559 \\
1341,1156\end{array}$ & $\begin{array}{l}0.78-0.88(3 \mathrm{H}, \mathrm{m}), 1.16-1.29(4 \mathrm{H}, \mathrm{m}), 2.63 \\
(3 \mathrm{H}, \mathrm{s}), 2.90-2.97(2 \mathrm{H}, \mathrm{m}), 5.69(\mathrm{H}, \mathrm{br}), 6.30 \\
(1 \mathrm{H}, \mathrm{br}), 7.46(1 \mathrm{H}, \mathrm{s}), 8.31(1 \mathrm{H}, \mathrm{s}), 8.75(1 \mathrm{H}, \mathrm{s})\end{array}$ \\
\hline BSU-9 & $-\mathrm{CH}_{2} \mathrm{CH}\left(\mathrm{CH}_{3}\right)_{2}$ & $\mathrm{H}$ & $-\mathrm{CH}_{3}$ & 414.9958 & 81 & $109-110$ & $\begin{array}{l}3370,3067,1752 \\
1681,1620,1548 \\
1342,1152\end{array}$ & $\begin{array}{l}0.74-0.83(6 \mathrm{H}, \mathrm{m}), 1.53-1.62(1 \mathrm{H}, \mathrm{m}), 2.64 \\
(3 \mathrm{H}, \mathrm{s}), 2.73-2.82(2 \mathrm{H}, \mathrm{m}), 7.68(1 \mathrm{H}, \mathrm{s}), 8.30 \\
(1 \mathrm{H}, \mathrm{s}), 8.75(1 \mathrm{H}, \mathrm{s})\end{array}$ \\
\hline BSU-10 & $-\mathrm{CH}_{2}\left(\mathrm{CH}_{2}\right)_{3} \mathrm{CH}_{3}$ & $\mathrm{H}$ & $-\mathrm{CH}_{3}$ & 429.0114 & 65 & $117-119$ & $\begin{array}{l}3371,3068,1750 \\
1682,1617,1545 \\
1343,1152\end{array}$ & $\begin{array}{l}0.78-0.86(3 \mathrm{H}, \mathrm{m}), 1.12-1.32(6 \mathrm{H}, \mathrm{m}), 2.63 \\
(3 \mathrm{H}, \mathrm{s}), 2.84-2.88(2 \mathrm{H}, \mathrm{t}), 6.13(1 \mathrm{H}, \mathrm{br}), 7.40 \\
(1 \mathrm{H}, \mathrm{s}), 8.26(1 \mathrm{H}, \mathrm{s}), 8.73(1 \mathrm{H}, \mathrm{s})\end{array}$ \\
\hline BSU-11 & $-\mathrm{CH}_{2}\left(\mathrm{CH}_{2}\right)_{6} \mathrm{CH}_{3}$ & $\mathrm{H}$ & $-\mathrm{CH}_{3}$ & 471.0580 & 78 & $121-124$ & $\begin{array}{l}3380,3072,1720 \\
1683,1619,1549 \\
1343,1154\end{array}$ & $\begin{array}{l}0.81-0.86(3 \mathrm{H}, \mathrm{t}), 1.08-1.36(12 \mathrm{H}, \mathrm{m},), 2.62 \\
(3 \mathrm{H}, \mathrm{s}), 2.91-2.93(2 \mathrm{H}, \mathrm{m}), 5.32(1 \mathrm{H}, \mathrm{br}), 7.38 \\
(1 \mathrm{H}, \mathrm{s}), 8.23(1 \mathrm{H}, \mathrm{s}), 8.74(1 \mathrm{H}, \mathrm{s})\end{array}$ \\
\hline BSU-12 & & $-\mathrm{CH}_{3}$ & $-\mathrm{CH}_{3}$ & 448.9801 & 57 & $198-200$ & $\begin{array}{l}3334,1716,1613 \\
1601,1544,1334 \\
1150\end{array}$ & $\begin{array}{l}2.61(3 \mathrm{H}, \mathrm{s}), 2.69(3 \mathrm{H}, \mathrm{s}), 6.81-6.86(1 \mathrm{H}, \mathrm{t}), \\
7.11-7.16(2 \mathrm{H}, \mathrm{t}), 7.34-7.58(3 \mathrm{H}, \mathrm{m}), 8.30(1 \mathrm{H}, \\
\mathrm{s}), 8.55(1 \mathrm{H}, \mathrm{br})\end{array}$ \\
\hline BSU-13 & $-\mathrm{CH}_{2}\left(\mathrm{CH}_{2}\right)_{2} \mathrm{CH}_{3}$ & $-\mathrm{CH}_{3}$ & $-\mathrm{CH}_{3}$ & 429.0125 & 42 & $220-221$ & $\begin{array}{l}3369,3078,1741 \\
1675,1642,1548 \\
1330,1154\end{array}$ & $\begin{array}{l}0.76-0.85(3 \mathrm{H}, \mathrm{t}), 1.11-1.26(4 \mathrm{H}, \mathrm{m}), 2.60(3 \mathrm{H}, \\
\mathrm{s}), 2.63(3 \mathrm{H}, \mathrm{s}), 2.86-2.88(2 \mathrm{H}, \mathrm{m}), 6.22(1 \mathrm{H}, \\
\mathrm{br}), 7.42(1 \mathrm{H}, \mathrm{s}), 8.25(1 \mathrm{H}, \mathrm{s})\end{array}$ \\
\hline BSU-14 & $-\mathrm{CH}_{2}\left(\mathrm{CH}_{2}\right)_{3} \mathrm{CH}_{3}$ & $-\mathrm{CH}_{3}$ & $-\mathrm{CH}_{3}$ & 443.0270 & 59 & $168-169$ & $\begin{array}{l}3355,1741,1676 \\
1604,1548,1332, \\
1155\end{array}$ & $\begin{array}{l}\text { 0.76-0.81(3H,t), } 1.09-1.30(6 \mathrm{H}, \mathrm{m}), 2.60(3 \mathrm{H}, \\
\mathrm{s}), 2.64(3 \mathrm{H}, \mathrm{s}), 2.85-2.88(2 \mathrm{H}, \mathrm{m}), 7.44(1 \mathrm{H}, \\
\mathrm{s}), 8.26(1 \mathrm{H}, \mathrm{s})\end{array}$ \\
\hline
\end{tabular}

Study on pharmacodynamics: Fourteen compounds selected from the initial screening out of the active compounds with hypoglycemic effect were continued to carry out pharmacodynamic studies. The methods were as follows: 60 mice were divided into 6 groups randomly by the weight each time and intragastric administration of different doses of the drug, $200,130,80,50$, and $30 \mathrm{mg} / \mathrm{kg}$, respectively; another group was given $0.5 \% \mathrm{CMC}-\mathrm{Na}$; giving a total of 14 times. The concentrations of blood glucose were determined before and after administration of two different rats, respectively. The method was as follows: After blooding from the venous plexus of the eye socket of the mouse with the capillary tube and centrifuging (3000 rpm, $10 \mathrm{~min}$ ), $10 \mu \mathrm{L}$ serum was taken to determine the concentration of the glucose by glucose kit (GOD-PAP). The $\mathrm{E}_{\max }, \mathrm{K}, \mathrm{D}_{50}$ and avidity index $\mathrm{PD}_{2}$ of each drug were calculated based on the relationship between the depressed percentage of the concentration of blood glucose before and after drug administration and dosage by Scott method (Table-2).

Analysis of structure-activity relationship: The energy optimization of molecular structure, the calculation of structure parameter and the analysis of structure-activity relationship were all carried out on the SGI-4D computer. The molecular structure of compound was optimized and the structure parameters were calculated by using the POLYGEN software package, which used QUANTA (90.0919 Edition) as the main procedures. In this paper the study on structure-activity relationship was stepwise multiple linear regression analysis by using SAS (Statistical Analysis System) program. The low active contribution parameters were deleted automatically through the two critical values (F1 and F2) of the control program in the calculation process. After inputting molecular 
TABLE-2

PHARMACODYNAMIC PARAMETERS OF COUMARIN SULFONYLUREA COMPOUNDS ON BLOOD GLUCOSE LEVEL OF NORMAL MICE $(x \pm s, n=10)$

\begin{tabular}{|c|c|c|c|c|c|c|c|c|}
\hline Drugs & $\mathrm{R}$ & $\mathrm{R}_{1}$ & $\mathrm{R}_{2}$ & $\begin{array}{l}\mathrm{E}_{\max } \\
(\%)\end{array}$ & $\mathrm{K}$ & $\begin{array}{c}\mathrm{D}_{50} \\
(\mathrm{~mol} / \mathrm{L})\end{array}$ & $\begin{array}{c}\mathrm{D}_{50} \\
(\mathrm{mg} / \mathrm{kg})\end{array}$ & $\mathrm{PD}_{2}$ \\
\hline BSU-1 & $-\mathrm{CH}_{2} \mathrm{CH}_{2} \mathrm{CH}_{3}$ & $\mathrm{H}$ & $\mathrm{H}$ & 9.49 & 0.0017 & 0.0017 & 13.26 & 2.77 \\
\hline BSU-2 & $-\mathrm{CH}_{2}\left(\mathrm{CH}_{2}\right)_{2} \mathrm{CH}_{3}$ & $\mathrm{H}$ & $\mathrm{H}$ & 48.05 & 0.0050 & 0.0050 & 40.09 & 2.30 \\
\hline BSU-3 & $-\mathrm{CH}_{2} \mathrm{CH}\left(\mathrm{CH}_{3}\right)_{2}$ & $\mathrm{H}$ & $\mathrm{H}$ & 20.00 & 0.0010 & 0.0010 & 8.04 & 3.00 \\
\hline BSU-4 & $-\mathrm{CH}_{2}\left(\mathrm{CH}_{2}\right)_{3} \mathrm{CH}_{3}$ & $\mathrm{H}$ & $\mathrm{H}$ & 15.02 & 0.0046 & 0.0046 & 38.42 & 2.34 \\
\hline BSU-5 & & $\mathrm{H}$ & $-\mathrm{CH}_{3}$ & 30.30 & 0.0067 & 0.0067 & 60.73 & 2.17 \\
\hline BSU-6 & & $\mathrm{H}$ & $-\mathrm{CH}_{3}$ & 51.28 & 0.0015 & 0.0015 & 13.09 & 2.82 \\
\hline BSU-7 & $\mathrm{H}_{3} \mathrm{C}=\mathrm{CH}_{3}$ & $\mathrm{H}$ & $-\mathrm{CH}_{3}$ & 13.66 & 0.0091 & 0.0091 & 84.88 & 2.04 \\
\hline BSU-8 & $-\mathrm{CH}_{2}\left(\mathrm{CH}_{2}\right)_{2} \mathrm{CH}_{3}$ & $\mathrm{H}$ & $-\mathrm{CH}_{3}$ & 20.41 & 0.0010 & 0.0010 & 8.735 & 3.00 \\
\hline BSU-9 & $-\mathrm{CH}_{2} \mathrm{CH}\left(\mathrm{CH}_{3}\right)_{2}$ & $\mathrm{H}$ & $-\mathrm{CH}_{3}$ & 50.00 & 0.0072 & 0.0072 & 60.25 & 2.14 \\
\hline BSU-10 & $-\mathrm{CH}_{2}\left(\mathrm{CH}_{2}\right)_{3} \mathrm{CH}_{3}$ & $\mathrm{H}$ & $-\mathrm{CH}_{3}$ & 12.66 & 0.0020 & 0.0020 & 17.59 & 2.70 \\
\hline BSU-11 & $-\mathrm{CH}_{2}\left(\mathrm{CH}_{2}\right)_{6} \mathrm{CH}_{3}$ & $\mathrm{H}$ & $-\mathrm{CH}_{3}$ & 55.87 & 0.0025 & 0.0025 & 24.02 & 2.60 \\
\hline BSU-12 & , & $-\mathrm{CH}_{3}$ & $-\mathrm{CH}_{3}$ & 23.15 & 0.0106 & 0.0106 & 95.31 & 1.97 \\
\hline BSU-13 & $-\mathrm{CH}_{2}\left(\mathrm{CH}_{2}\right)_{2} \mathrm{CH}_{3}$ & $-\mathrm{CH}_{3}$ & $-\mathrm{CH}_{3}$ & 12.15 & 0.0112 & 0.0112 & 96.07 & 1.95 \\
\hline BSU-14 & $\mathrm{CH}_{2}\left(\mathrm{CH}_{2}\right)_{3} \mathrm{CH}_{3}$ & $-\mathrm{CH}_{3}$ & $-\mathrm{CH}_{3}$ & 9.55 & 0.0111 & 0.0111 & 98.51 & 1.95 \\
\hline
\end{tabular}

$\mathrm{E}_{\max }=$ Maximum hypoglycemic effect of the dose; $\mathrm{K}=$ the drug dose of dose response got $50 \%$ total intensity; $\mathrm{D}_{50}=$ the actuating quantity of half effect; $\mathrm{PD}_{2}=$ Avidity index, the negative logarithm of $\mathrm{K}$ value.

structure used "ChemNote" as subroutine, the computer numbered each atom automatically and the established X, Y, $\mathrm{Z}$ coordinates and the file (Residue Topology File, RTF) of molecular residue topology. And then the energy optimization of molecular structure was carried out by using the subroutine of "CHARMm", which used RTF as the data structure of CHARM (CHARMm Date Structure) to carry on structural search and analysis (Search and Analysis). The computer performed optimization program continuously to make the force field of RMS close to or equal to zero, finding the lowest energy of threedimensional molecular structure, namely the preferred conformation of compound. Twenty three parameters of molecular mechanics structure of the target compounds were calculated based on the obtained preferred conformation of compounds by using MM2 molecular mechanics program, which involved the stereo factor, power factor and the hydrophobic factor, of the compound. The parts of molecular mechanics structure parameters of target compounds $\left(\mathrm{X}_{1}-\mathrm{X}_{25}\right)$ were shown in Table-3.

$\mathrm{X}_{1}$-the lowest energy of molecular $(\mathrm{Kcal} / \mathrm{mol}) ; \mathrm{X}_{2}$-the total bond energy of molecular $(\mathrm{Kcal} / \mathrm{mol}) ; \mathrm{X}_{3}$-the total bond angle of molecular $(\mathrm{Kcal} / \mathrm{mol}) ; \mathrm{X}_{4}$-the total dihedral angle energy of molecular $(\mathrm{Kcal} / \mathrm{mol}) ; \mathrm{X}_{5}$-the total non regular energy of molecular (Kcal/mol); $\mathrm{X}_{6}$-the total Lennard-Jones energy of molecular $(\mathrm{Kcal} / \mathrm{mol}) ; \mathrm{X}_{7}$-the total electrostatic energy of molecular $(\mathrm{Kcal} / \mathrm{mol}) ; \mathrm{X}_{8}$-the dipole moment of molecular (D); $\mathrm{X}_{9}$-the van der Waals volume of molecular $\left(\AA^{3}\right) ; X_{10}$-the affinity surface area of molecular $\left(\AA^{2}\right) ; X_{11}$-the hydrophobic surface area of molecular $\left(\AA^{2}\right) ; X_{12}$-the total surface area of molecular $\left(\AA^{2}\right) ; X_{13}$-the total volume of molecular $\left(\AA^{3}\right)$; $\mathrm{X}_{14}$-solvent accessible affinity surface area $\left(\AA^{2}\right) ; \mathrm{X}_{15}$-solvent accessible hydrophobic surface area $\left(\AA^{2}\right) ; X_{16}$-solvent accessible total surface area $\left(\AA^{2}\right) ; X_{17}$-solvent accessible total volume $\left(\AA^{3}\right) ; \mathrm{X}_{18}$-the carbon atomic charge of mother nucleus of 2 position; $\mathrm{X}_{19}$-the carbon atomic charge of mother nucleus of 3 position; $\mathrm{X}_{20}$-the charge of sulfur atom; $\mathrm{X}_{21}$-the nitrogen atom charge of urea; $\mathrm{X}_{22}$-the included angle between sulfonyl and parent nucleus $\left({ }^{\circ}\right) ; \mathrm{X}_{23}$-the dihedral angle between the perssad of sulfonyl urea and the parent nucleus (DEG); $\mathrm{X}_{24}$-the distance between the carbon atoms of mother nucleus of 7 position with carbon atomic connected to the perssad of urea; $\mathrm{X}_{25}$-the farthest distance between the carbon atom of mother nucleus of 7 position with the carbon atom connected to the substituted perssad of urea.

\section{RESULTS AND DISCUSSION}

The equation (QSAR) between molecular mechanics parameters and the quantitative structure-activity relationship of hypoglycemic activity was obtained by using the mechanics structure parameter of molecular as a variable and the stepwise multiple linear regressions for hypoglycemic activity:

$$
\begin{gathered}
\mathrm{Y}=3.0726-0.0299 \mathrm{X} 1 \\
\mathrm{~N}=15, \mathrm{R}=0.977041, \mathrm{~S}=0.302434, \mathrm{~F}=11.00224
\end{gathered}
$$

Y: refers to the avidity index of hypoglycemic activity $\mathbf{P D}_{2}$ : This equation showed that the hypoglycemic activity of 3-bromocoumarin sulfonylurea compound was negatively related to the minimum energy of compound. The preliminary conclusion was obtained by the comparison of the changes of compound structure: when the substituent group of the perssad of urea was fatty group, the energy of compound was low energy and the activity was high. In addition, the following preliminary conclusion also was got according to the hypoglycemic activity data of measured compounds: the substituent group of the perssad of urea should have a certain size and lipophilic ability; when the number of carbon atoms was 3-8, the compound generally had the obvious hypoglycemic activity and the compound had higher activity as the amount of substituent group was 4; comparing the hypoglycemic activity of the coumarin sulphonyl urea compound substituted by bromine atoms with non substitutional compound, introducing bromine could enhance activity and the $\mathrm{PD}_{2}$ value 
STRUCTURAL PARAMETERS OF SELECTED COMPOUNDS BASED ON MM2 PROGRAM CALCULATION

\begin{tabular}{|c|c|c|c|c|c|c|c|c|c|c|c|c|c|}
\hline \multirow{2}{*}{ Compd. } & $\mathrm{X}_{1}$ & $\mathrm{X}_{2}$ & $X_{3}$ & $X_{4}$ & $\mathrm{X}_{5}$ & $\mathrm{X}_{6}$ & $X_{7}$ & $\mathrm{X}_{8}$ & $\mathrm{X}_{9}$ & $\mathrm{X}_{10}$ & $\mathrm{X}_{11}$ & $X_{12}$ & $X_{13}$ \\
\hline & $\mathrm{X}_{14}$ & $\mathrm{X}_{15}$ & $\mathrm{X}_{16}$ & $X_{17}$ & $\mathrm{X}_{18}$ & $\mathrm{X}_{19}$ & $\mathrm{X}_{20}$ & $\mathrm{X}_{21}$ & $\mathrm{X}_{22}$ & $\mathrm{X}_{23}$ & $\mathrm{X}_{24}$ & $X_{25}$ & $\mathrm{Y}$ \\
\hline \multirow{2}{*}{ BSU-1 } & 11.2227 & 1.418 & 2.329 & 0.3428 & 0.6871 & 6.899 & -0.453 & 6.812 & 266.06 & 195 & 98 & 294 & 268.2 \\
\hline & 167 & 383 & 551 & 861.2 & 0.589 & -0.151 & 0.389 & -0.311 & 137.90 & 48.15 & 6.465 & 8.800 & 2.77 \\
\hline \multirow{2}{*}{ BSU-2 } & 11.7191 & 1.564 & 2.795 & 0.1753 & 0.3326 & 7.505 & -0.653 & 9.093 & 270.62 & 207 & 103 & 311 & 286.8 \\
\hline & 169 & 414 & 583 & 915.0 & 0.578 & -0.162 & 0.378 & -0.322 & 137.90 & 48.15 & 6.465 & 9.814 & 2.30 \\
\hline \multirow{2}{*}{ BSU-3 } & 8.0596 & 1.843 & 3.515 & 0.6148 & 0.5661 & 7.467 & -5.947 & 7.579 & 273.63 & 201 & 102 & 304 & 284.6 \\
\hline & 155 & 407 & 562 & 894.8 & 0.582 & -0.157 & 0.382 & -0.317 & 137.90 & 48.15 & 6.465 & 8.800 & 3.00 \\
\hline \multirow{2}{*}{ BSU-4 } & 14.5257 & 1.697 & 3.076 & 0.1762 & 0.0252 & 7.828 & 1.723 & 9.885 & 185.49 & 46 & 285 & 331 & 304.6 \\
\hline & 169 & 444 & 612 & 963.5 & 0.576 & -0.164 & 0.376 & -0.324 & 122.06 & 7.96 & 6.638 & 11.49 & 2.34 \\
\hline \multirow{2}{*}{ BSU-5 } & 23.7672 & 3.135 & 7.332 & 4.659 & 1.148 & 15.41 & -7.919 & 6.612 & 318.67 & 38 & 305 & 343 & 338.2 \\
\hline & 140 & 470 & 610 & 995.1 & 0.576 & -0.164 & 0.376 & -0.324 & 120.01 & 97.89 & 7.351 & 10.18 & 2.17 \\
\hline \multirow{2}{*}{ BSU-6 } & 21.4361 & 2.603 & 5.669 & 3.391 & 1.775 & 14.28 & -6.278 & 6.244 & 306.18 & 40 & 292 & 332 & 319.8 \\
\hline & 149 & 445 & 594 & 954.3 & 0.578 & -0.162 & 0.378 & -0.322 & 137.90 & 48.15 & 6.365 & 9.108 & 2.82 \\
\hline \multirow{2}{*}{ BSU-7 } & 40.3544 & 4.072 & 7.688 & 11.57 & 3.478 & 17.48 & -3.934 & 7.626 & 339.63 & 39 & 321 & 360 & 361.5 \\
\hline & 144 & 499 & 642 & 1065.5 & 0.570 & -0.170 & 0.370 & -0.330 & 155.98 & 33.97 & 6.614 & 10.04 & 2.04 \\
\hline BSU-8 & 156 & 415 & 570 & 901.1 & 0.586 & -0.154 & 0.386 & -0.314 & 137.90 & 48.15 & 6.465 & 8.800 & 3.00 \\
\hline \multirow{2}{*}{ BSU-9 } & 24.5562 & 2.206 & 2.707 & 7.524 & 0.9175 & 8.180 & 3.021 & 7.814 & 291.95 & 209 & 109 & 318 & 301.8 \\
\hline & 154 & 433 & 587 & 937.5 & 0.580 & -0.160 & 0.380 & -0.320 & 168.64 & 45.09 & 6.708 & 9.067 & 2.14 \\
\hline \multirow{2}{*}{ BSU-10 } & 23.1076 & 2.033 & 2.999 & 6.618 & 0.7753 & 8.458 & 2.225 & 9.559 & 301.19 & 43 & 295 & 338 & 316.4 \\
\hline & 158 & 469 & 627 & 999.1 & 0.574 & -0.166 & 0.374 & -0.326 & 164.07 & 41.55 & 6.697 & 11.52 & 2.70 \\
\hline \multirow{2}{*}{ BSU-11 } & 27.8884 & 2.383 & 3.571 & 5.796 & 1.069 & 9.529 & 5.541 & 11.68 & 342.47 & 254 & 132 & 386 & 365.5 \\
\hline & 158 & 555 & 714 & 1141.0 & 0.570 & -0.170 & 0.370 & -0.330 & 158.73 & 35.24 & 6.686 & 15.16 & 2.60 \\
\hline \multirow{2}{*}{ BSU-12 } & 32.1900 & 3.118 & 6.262 & 7.819 & 2.084 & 16.23 & -3.323 & 6.840 & 313.82 & 218 & 122 & 340 & 335.7 \\
\hline & 156 & 447 & 603 & 980.1 & 0.574 & -0.166 & 0.374 & -0.326 & 137.90 & 48.15 & 6.365 & 9.108 & 1.97 \\
\hline \multirow{2}{*}{ BSU-13 } & 24.7998 & 2.383 & 4.203 & 6.010 & 2.271 & 10.11 & -0.174 & 8.120 & 300.20 & 44 & 290 & 334 & 317.6 \\
\hline & 158 & 456 & 613 & 983.5 & 0.572 & -0.168 & 0.372 & -0.328 & 153.60 & 29.62 & 6.679 & 10.08 & 1.95 \\
\hline \multirow{2}{*}{ BSU-14 } & 26.7433 & 2.495 & 4.532 & 5.543 & 2.295 & 10.43 & 1.448 & 8.654 & 312.49 & 230 & 117 & 347 & 330.3 \\
\hline & 158 & 484 & 642 & 1031.4 & 0.570 & -0.170 & 0.370 & -0.330 & 150.90 & 27.38 & 6.695 & 11.51 & 1.95 \\
\hline
\end{tabular}

was relatively high; the space structure of active compounds showed "U " type.

\section{ACKNOWLEDGEMENTS}

The authors thank research fund of Key Laboratory for Advanced Technology in Environmental Protection of Jiangsu Province (No. AE201127) for the financial support.

\section{REFERENCES}

1. J.P. Weng and Z.M. Huang, Chin. J. Gen. Pract., 3, 47 (2004).
2. F.Z. Shen, Q.M. Chen, H.F. Liu and M.Z. Xie, Acta Pharm. Sinica, 24, 391 (1989).

3. J.S. Mishkinsky, A. Goldschmied, B. Joseph, Z. Ahronson and F.G. Sulman, Arch. Int. Pharmacodyn. Ther., 210, 27 (1974).

4. S.Y. Xu, H.P. Zeng and C.W. Wei, Chinese J. Synthetic Chem., 12, 340 (2004).

5. S. Sethna and R. Phadke, The Pechmann reaction. In: Organic Reaction, Volume VII, Chapter 1 (1953).

6. K.M. Jainamma and S. Sethna, J. Indian. Chem. Soc., 50, 790 (1973).

7. T.J. Thompson and R. Herbert, J. Chem. Soc, 47, 2556 (1925).

8. Y.X. Su and J.Q. Yang, J. Hebei Normal University, 26, 162 (2002). 